\title{
A phytoplankton bloom and associated processes observed with a long-term moored system in antarctic waters*
}

\author{
Mitsuo Fukuchi ${ }^{1}$, Hiroshi Hattori ${ }^{2}$, Hiroshi Sasaki ${ }^{2}$, Takao Hoshiai ${ }^{1}$ \\ ${ }^{1}$ National Institute of Polar Research, 9-10, Kaga 1-chome, Itabashi-ku, Tokyo 173, Japan \\ ${ }^{2}$ Faculty of Agriculture, Tohoku University, 1-1, Tsutsumidori-amamiya cho, Sendai 980, Japan
}

\begin{abstract}
A moored system was designed for monitoring both long- and short-term temporal variations in phytoplankton communities. It consisted of a chlorophyll buoy, a current meter and a sequential, multiple-sampling sediment trap, set at depths of 52,57 and $120 \mathrm{~m}$, respectively. The system was deployed at $70^{\circ} 11.54^{\prime} \mathrm{S}, 24^{\circ} 18.68^{\prime} \mathrm{E}$ in Breid Bay, Antarctica, from 28 December 1985 to 13 February 1986. A total of 1127 hourly data sets and 12 trap samples were obtained. Equivalent chlorophyll a concentration fluctuated mainly in the range 0.69 to $5.60 \mathrm{ug} \mathrm{l}^{-1}$; values tended to decrease toward early February. Tides caused the depth of the buoy to vary between 51.0 and $52.9 \mathrm{~m}$. A strong positive correlation was found between chlorophyll a level and water temperature and indicates a possible advective water movement in the Bay. Vertical flux of particulate pigments showed a marked increase in mid-January, 3.5 to $10.5 \mathrm{~d}$ after an increase was observed in surface chlorophyll. Sediment samples were dominated by intact cells of Thalassiosira antarctica throughout the period of observation.
\end{abstract}

\section{INTRODUCTION}

The importance of time series observations in biological oceanography has frequently been stressed since the publication of a technical paper on the methodology of monitoring the life in the ocean (UNESCO 1973). Sophisticated systems that require continuous manned operation, such as the LHPR system (Longhurst \& Williams 1976) and Bat fish system (Herman \& Mitchell 1981), have been used to obtain limited time series data. Continuous observations with unmanned instruments were successfully carried out by Whitledge \& Wirick $(1983,1986)$, who measured chlorophyll concentration for periods ranging from 6 to $11 \mathrm{~d}$ off Long Island, New York.

In order to clarify and evaluate bloom processes, it is necessary to observe temporal changes in phytoplankton standing stock in the euphotic layer and the downward flux from the surface layer (Zeitzschel et al. 1978,

\footnotetext{
- Part of this paper was presented at the IOC/CCAMLR Scientific Seminar on Antarctic Ocean Variability and its Influence on Marine Living Resources, Particularly Krill; Paris, 2-6 June 1987
}

Jannasch et al. 1980). We have designed a moored monitoring system which was deployed for $47 \mathrm{~d}$ at a site near the coast of Antarctica. Very little time series information is available for antarctic coastal waters because of their remoteness and harshness. This paper describes the moored system and the initial data it recorded during an antarctic bloom.

\section{MATERIALS AND METHODS}

The moored system consists of a continuous chlorophyll-measuring buoy, a current meter and a sequential multiple-sampling sediment trap (Fig. 1) set at depths of 52,57 and $120 \mathrm{~m}$, respectively. An acoustic release was set at $2.5 \mathrm{~m}$ above the bottom.

The chlorophyll-measuring buoy contains 3 sensors (fluorometer, thermistor and pressure transducer), a data logger and a power unit (Fig. 2). Characteristics of the buoy are given in Table 1 . Two windows of the fluorometer are cleaned by mechanical brushing to remove possible fouling organisms.

A block diagram of the chlorophyll-measuring buoy is shown in Fig. 3. The data logger is temporarily con- 


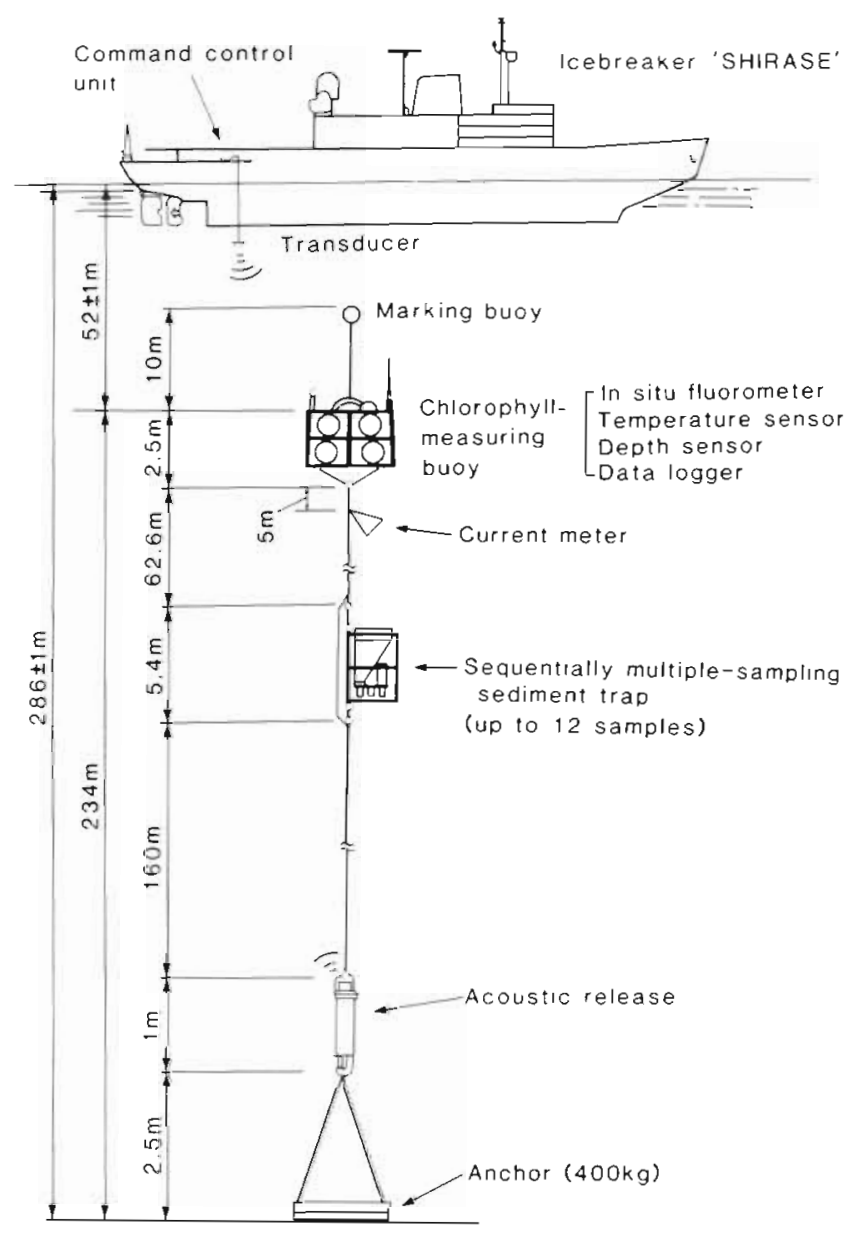

Fig. 1. Mooring array of the monitoring system in Breid Bay, Antarctica, December 1985 to February 1986

nected to a personal computer for setting up sampling parameters and for retrieving recorded data. The data logger controls the time intervals for measuring and recording the data with a program on an 8 kbyte ROM (read-only memory) as follows. An hourly signal from a quartz timer opens a power circuit which powers the central processing unit (CPU) for 5.5 min. During this period, readings are made by the fluorometer (60 s), thermistor (15 s) and pressure transducer (30 s). This was followed by a 2 -min window brushing. A second set of readings was made after the window brushing to determine the rate of fouling of the windows. Power was conserved by using CMOS (complementary metal oxide semiconductor) integrated circuits and by turning off the power circuit between sampling periods. Digital data on fluorescence intensity, temperature and depth are stored on a 64 kbyte RAM (random access memory). The RAM is capable of storing 3 mo of data with a 1 h sampling interval. Continuous power for the timer and RAM is supplied by a separate circuit using lithium batteries.

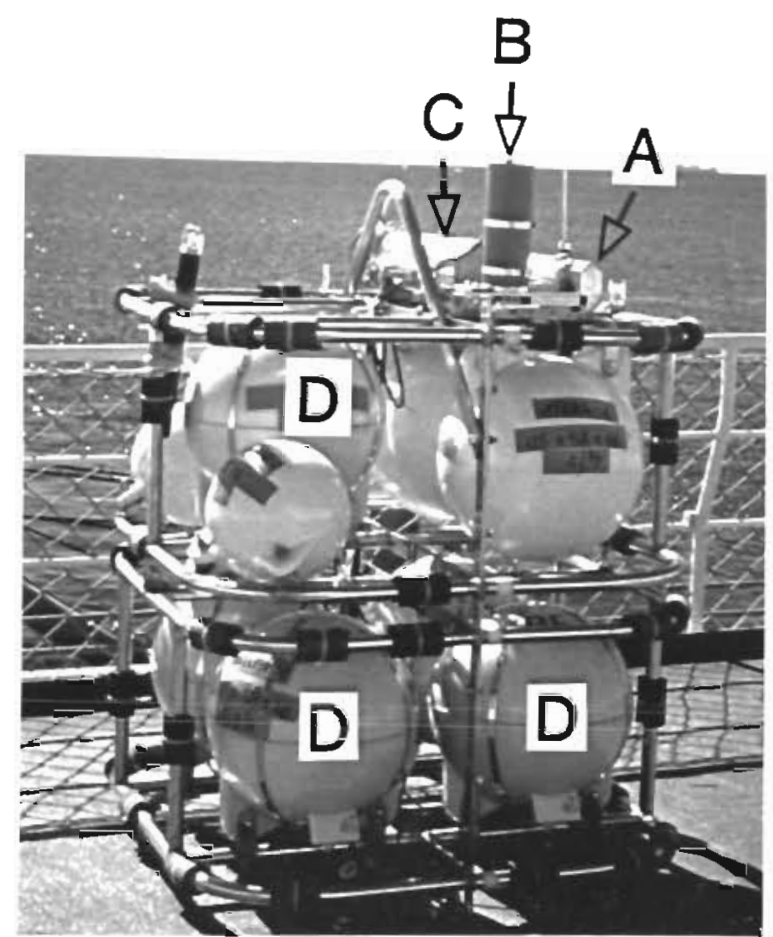

Fig. 2. Continuous chlorophyll-measuring recording buoy on deck of icebreaker 'Shirasc' A beacon and a flasher are attached to the buoy. A: in situ fluorometer; B: window wiper; C: data logger; D: batteries

Table 1. Characteristics of chlorophyll-measuring buoy

\begin{tabular}{|c|c|}
\hline \multicolumn{2}{|c|}{ Size: $\quad 112 \mathrm{~L} \times 112 \mathrm{~W} \times 147 \mathrm{H} \mathrm{cm}$} \\
\hline Weight: $\begin{aligned} & 330 \mathrm{k} \\
& \text { (posit }\end{aligned}$ & $\begin{array}{l}g \text { in air, }-120 \mathrm{~kg} \text { in water } \\
\text { ive buoyancy) }\end{array}$ \\
\hline $\begin{array}{l}\text { Sensors: } \\
\quad \text { Fluoromete }\end{array}$ & $\begin{array}{l}\text { I Aquatracka } \\
\text { (Chelsea Envir. Inst. Ltd., UK) } \\
\text { Excitation wavelength } 400-440 \mathrm{~nm} \\
\text { Emission wavelength } \quad 600<\mathrm{nm} \\
\text { Sensitivity: Chlorophyll. } 0.1 \mu \mathrm{g} \mathrm{l}^{-1}\end{array}$ \\
\hline Thermistor & $\begin{array}{l}\text { PXA-64 (Takara Themistor Inc., Japan) } \\
\text { Range }-5+35^{\circ} \mathrm{C} \\
\text { Accuracy } \pm 0.1 \mathrm{C}^{\circ} \\
\text { Resolution } 0.01 \mathrm{C}^{\circ}\end{array}$ \\
\hline $\begin{array}{l}\text { Pressire } \\
\text { transducer }\end{array}$ & $\begin{array}{l}\text { P305D (Validyne Eng. Corp., USA) } \\
\text { Range } 0 \sim 35 \mathrm{kgf} \mathrm{cm}{ }^{-2} \\
\text { Accuracy } \pm 0.5 \% \mathrm{FS} \\
\text { Resolution } 0.02 \mathrm{~kg} \mathrm{~cm}^{-2}\end{array}$ \\
\hline Data logger: & $\begin{array}{l}90 \mathrm{~d} \text { at } 1 \mathrm{~h} \text { sampling rate } \\
\text { (1 set before and after washing) }\end{array}$ \\
\hline Power: & $\begin{array}{l}\text { DC } 12 \mathrm{~V}(36 \mathrm{AH}) \text { dryfit battery }(\mathrm{A} 200) \times 5 \\
\text { (Sonnenschein, FRG) }\end{array}$ \\
\hline
\end{tabular}




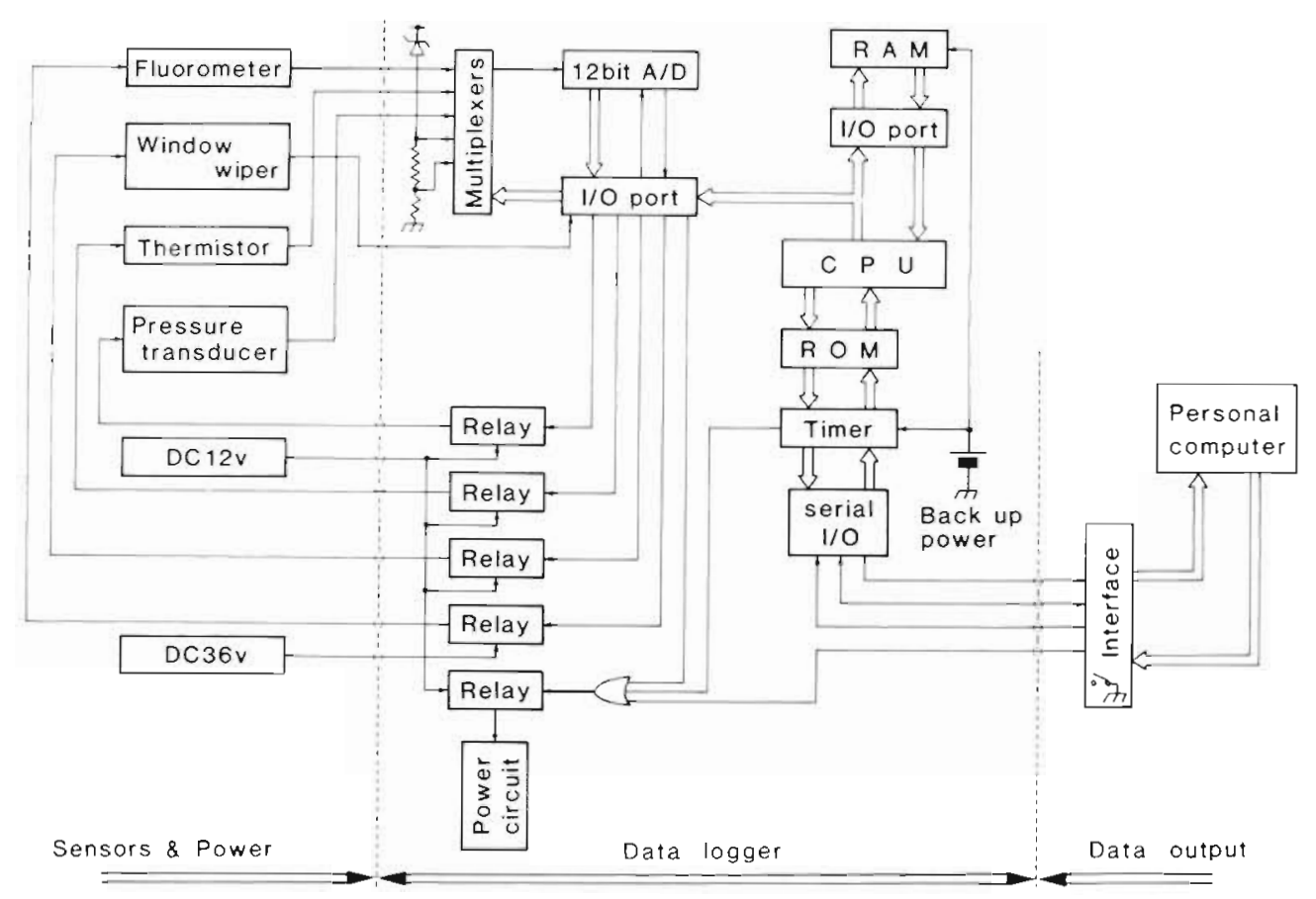

Fig. 3. Block diagram of continuous chlorophyll-measuring recording buoy

Fluorescence intensity was converted into chlorophyll a concentration based on a calibration. In vivo fluorescence values were compared with chlorophyll a values measured by the method of Strickland \& Parsons (1968) for the Bay water in December 1985. The following relation was found

$$
\operatorname{chl~} a=10^{(0.415 \mathrm{~V}-1.133)}
$$

where chl $a=$ chlorophyll a concentration in $\mu \mathrm{g} \mathrm{l}^{-1} ; V=$ fluorescence intensity expressed in volts. Spectral analyses of depth, chlorophyll a and temperature time series data were done on a personal computer.

A current meter with a temperature sensor (model 6011T, General Oceanics, USA) was used. All data were recorded on magnetic tape at $1 \mathrm{~h}$ intervals.

The time series sediment trap consists of a PVC cone, a control unit, and 12 sample bottles. The weight of the trap is $67.5 \mathrm{~kg}$ in air and $40.5 \mathrm{~kg}$ in water (Fig. 4). The PVC cone is $50 \mathrm{~cm}$ in diameter at the mouth, $4 \mathrm{~cm}$ in diameter at the bottom and $143 \mathrm{~cm}$ long. A honeycomb baffle $(3 \times 3 \mathrm{~cm}$ mesh, $10 \mathrm{~cm}$ deep) at the mouth prevents water turbulence. The cone is inclined to one side, so that the angles of the cone wall range from 0 to $20^{\circ}$ with respect to vertical. A 13 -position PVC turntable containing 12 sample bottles $(500 \mathrm{ml}$ capacity) and one empty hole was installed at the bottom of the cone. A control unit contains a step motor to rotate the turntable and 2 timers. One timer sets the delay time (from 1 to $9 \mathrm{~h}$ ) for starting the turntable rotation from the empty hole position to the position of the first

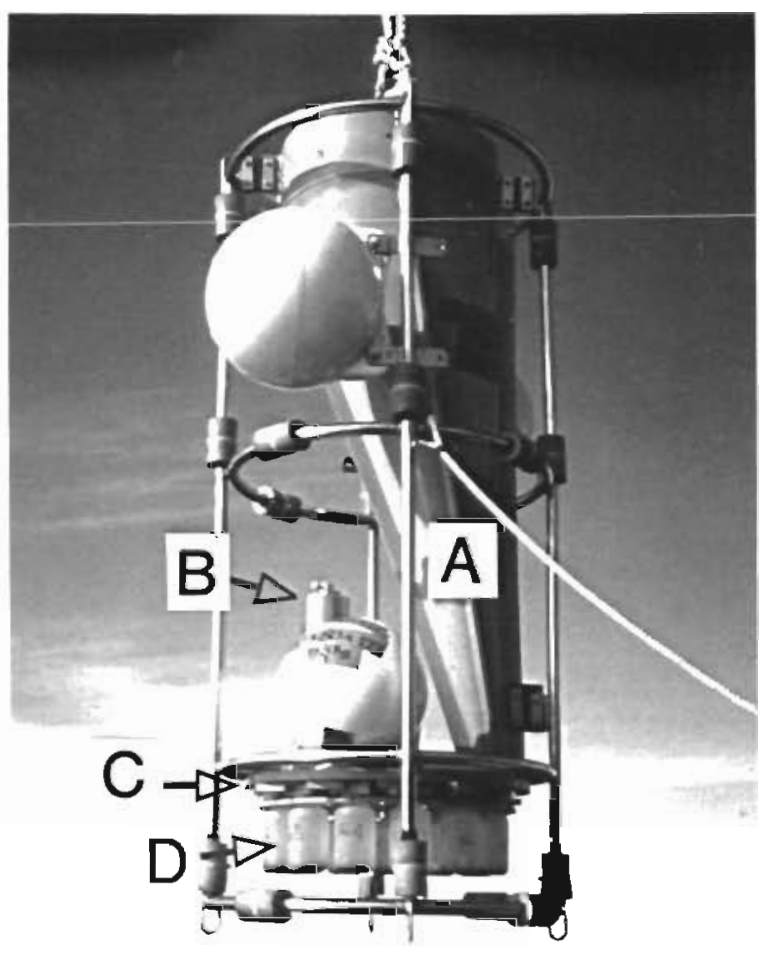

Fig. 4. Time series sediment trap. A: funnel-shaped collecting cone; B: control unit; $C$ : turntable; D: sample bottle

sample bottle. The other timer sets the sampling period (from 1 to $999 \mathrm{~h}$ ) for the bottles.

All samples collected by the sediment trap were 
divided into several aliquots immediately after the trap was retrieved. Chlorophyll a and phaeopigment concentrations were measured on board with a fluorometric method (Strickland \& Parsons 1968). Other aliquots were preserved in buffered formalin seawater for later observations and analyses on particle size, morphology and components. Particle size was determined with an Elzone ( $80 \mathrm{XY}$ ) particle counter (Particle Data Inc.).

Within several $n$ miles of the mooring position, temperature, salinity and chlorophyll $a$ at standard depths were measured at 6 stations on 25 to 27 December 1985 and 3 stations on 14 to 15 February.

\section{RESULTS}

\section{Field experiment}

The moored system was deployed at $70^{\circ} 11.54^{\prime} \mathrm{S}$, $24^{\circ} 18.68^{\prime} \mathrm{E}$ in Breid Bay, Antarctica. Water depth at this location is $286 \mathrm{~m}$. The Bay is rectangular in shape and measures ca $23 \mathrm{n}$ miles in the east-west direction and ca $10 \mathrm{n}$ miles in the north-south direction. Water depth in the Bay is 200 to $350 \mathrm{~m}$ (Steyaert 1973, Nishio et al. 1984). The Bay opens northward and the other 3 directions are bounded by ice shelves. During summer, the Bay usually becomes ice-free, while the north of the Bay is covered with pack ice.

The moored system was deployed on 28 December
1985 when the Bay was free of pack ice, and recovered on 13 February 1986 when pack ice was distributed around the mooring position. The chlorophyll-measuring buoy worked successfully for $47 \mathrm{~d}$ during which time 1127 data sets were obtained. The current meter also recorded hourly data. The sediment trap collected 12 samples, each representing a $3.5 \mathrm{~d}$ period, between 1800 LMT on 28 December and 1800 LMT on 8 February.

\section{Environmental conditions in December and February}

Vertical profiles of average temperature, salinity, sigma-t and chlorophyll $a$ in December and February are shown in Fig. 5.

Water temperatures were higher in December, and the standard deviations for shallower depths were larger in December. The thermocline deepened and standard deviations of temperature were small in February. The salinity profile in December was uniform and higher than 34.00. Standard deviations throughout the water column were small. In February, however, salinity in the surface layer ( 0 to $30 \mathrm{~m}$ ) decreased to less than 33.80 (with a large standard deviation) and a strong halocline formed between 30 and $50 \mathrm{~m}$. Sigma-t profiles were similar to salinity profiles in December and February. A strong pycnocline between 30 and $50 \mathrm{~m}$ formed in February.

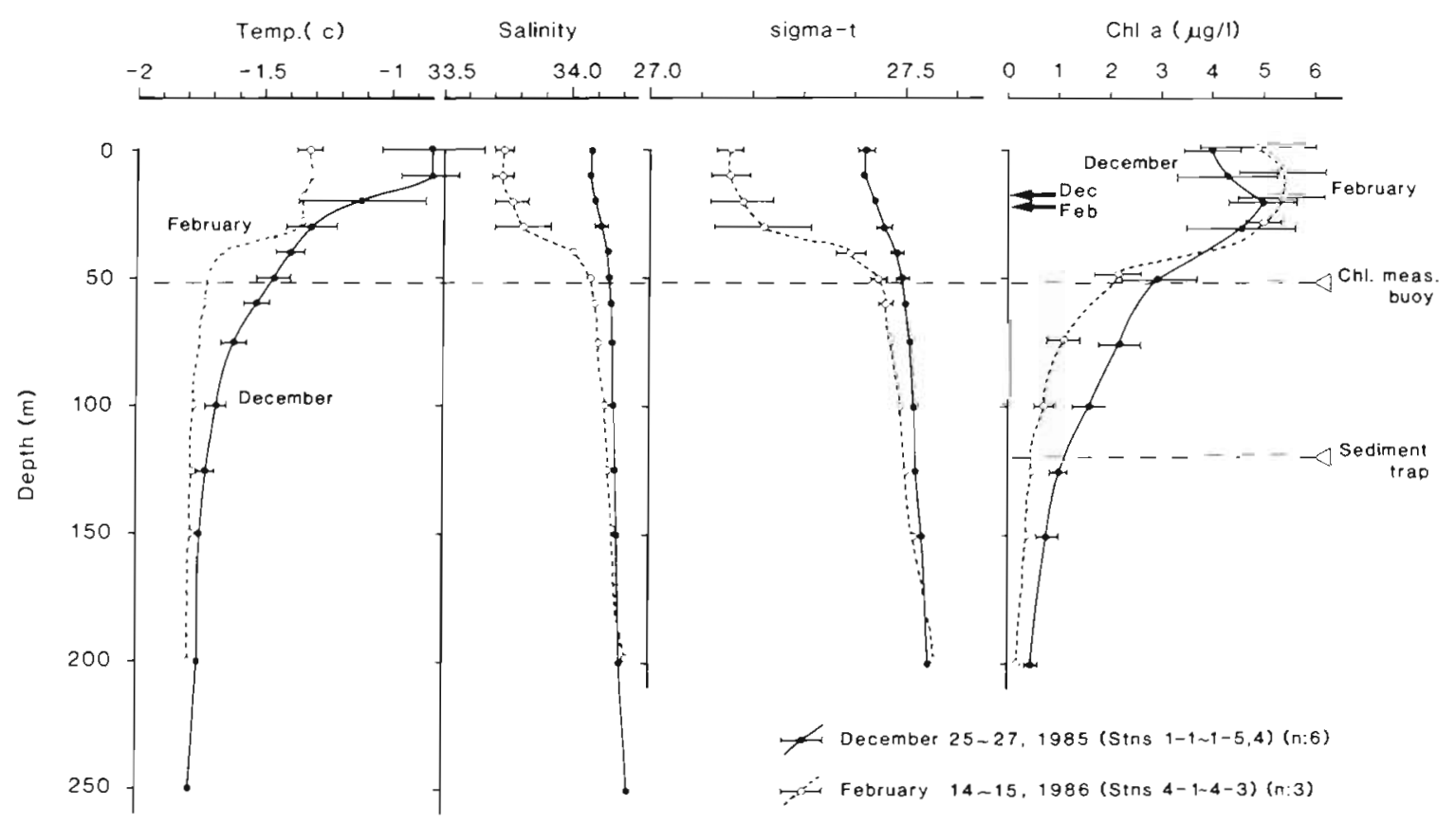

Fig. 5. Average vertical distribution of temperature, salinity, sigma-t and chlorophyll a in December 1985 and February 1986 Circles and horizontal bars indicate mean and standard deviation, respectively. Approximate depths of mooring chlorophyll measuring buoy and sediment trap are also indicated. Arrows indicate approximate depths of euphotic zone 
In contrast to temperature, salinity and sigma-t, vertical profiles of chlorophyll $a$ in December and February generally resembled each other, showing subsurface maxima $\left(4.97 \mathrm{mg} \mathrm{m}^{-3}\right.$ in December and $5.39 \mathrm{mg} \mathrm{m}^{-3}$ in February) at depths of ca $20 \mathrm{~m}$ with a marked decrease below $50 \mathrm{~m}$. However, integrated chlorophyll a standing stocks in the water column between 0 and $200 \mathrm{~m}$ were higher in December $\left(402.8 \mathrm{mg} \mathrm{m}^{-2}\right.$ ) than in February $\left(333.4 \mathrm{mg} \mathrm{m}^{-2}\right)$. The stocks above the pycnoline (0 to $30 \mathrm{~m}$ ) were higher in February $\left(156.6 \mathrm{mg} \mathrm{m}^{-2}\right.$ ), than in December (135.4 $\mathrm{mg} \mathrm{m}^{-2}$ ).

The chlorophyll-measuring buoy was set just below the pycnoline and below the subsurface chlorophyll $a$ maximum. The sediment trap was set in vertically uniform water having temperatures below $-1.7^{\circ} \mathrm{C}$ and salinities above 34.10 (Fig. 5). Euphotic depths (2.5 times Secchi depth) were 16.25 to $18.75 \mathrm{~m}$ in December and $22.50 \mathrm{~m}$ in February (Fig. 5).

\section{Time series data records for $47 \mathrm{~d}$}

Fig. 6 shows an example of the time series data for a 5 d period between 29 December and 2 January. Fluorescence intensities measured before and after cleaning the windows were found to be in close agreement throughout the $47 \mathrm{~d}$ observation period.

Data from $47 \mathrm{~d}$ of $1 \mathrm{~h}$ interval are shown in Fig. 7. Current velocity and temperature recorded by the current meter are also included. Current speed and direction changed periodically but the speed was always greater than about $25 \mathrm{~cm} \mathrm{~s}^{-1}(=0.5 \mathrm{kn})$. The depth of the buoy normally varied between 51.0 and $52.9 \mathrm{~m}$ but greater depths (down to $54.2 \mathrm{~m}$ ) were occa- sionally recorded when the current velocity was exceptionally large. A spectral analysis of depth data showed 3 pronounced peaks at frequencies of $12 \mathrm{~h}, 24 \mathrm{~h}$ and 14 to $15 \mathrm{~d}$. On the other hand, chlorophyll a and temperature fluctuated greatly but a spectral analysis showed no clear periodicities. Chlorophyll a fluctuated (0.69 to $\left.5.60 \mathrm{ug} \mathrm{l}^{-1}\right)$ in accordance with temperature fluctuation $\left(-1.29\right.$ to $\left.-1.80^{\circ} \mathrm{C}\right)$. Temperature recorded by the current meter fluctuated in the same way as the temperature recorded by the buoy.

\section{Time series sampling by sediment trap}

All of the sediment samples were dominated by the diatom Thalassiosira antarctica, with the most frequent size being about $20 \mu \mathrm{m}$ in diameter (Fig. 8). Less abundant organisms were Coscinodiscus sp., Nitzschia sp. and Foraminifera. Size frequency distributions of sinking particles showed a unimodal distribution around $20 \mu \mathrm{m}$ in diameter (equivalent spherical diameter) in each of the 12 samples. The total volume flux varied between $19.4 \mu \mathrm{lm}^{-2} \mathrm{~d}^{-1}$ (sample No. 11) and $451.4 \mu \mathrm{l}$ $\mathrm{m}^{-2} \mathrm{~d}^{-1}$ (sample No. 6). The most frequent size of particles $(20 \mu \mathrm{m})$ coincided with the size of $T$. antarctica. The flux of fecal pellets, although not presicely known, accounted for only a small part of the total flux. Most of the fecal pellets were 40 to $100 \mu \mathrm{m}$ wide and 60 to $200 \mu \mathrm{m}$ long.

The vertical flux of pigments varied between 0.31 and $4.54 \mathrm{mg} \mathrm{m} \mathrm{m}^{-2} \mathrm{~d}^{-1} \hat{0.09}$ to $2.14 \mathrm{mg}$ chlorophyll and 0.22 to $2.40 \mathrm{mg}$ phaeopigments) (Fig. 9c). The pigment flux reached a peak in sample No. 7 (18 to 22 January), one sampling period after the peak in volume flux.
Fig. 6. Time series data on depth, chlorophyll $a$ and temperature measured by the buoy for a $5 \mathrm{~d}$ period from 29 Dec 1985 to 2 Jan 1986. (-) Data obtained before, and (-...) after, washing the window of fluorometer

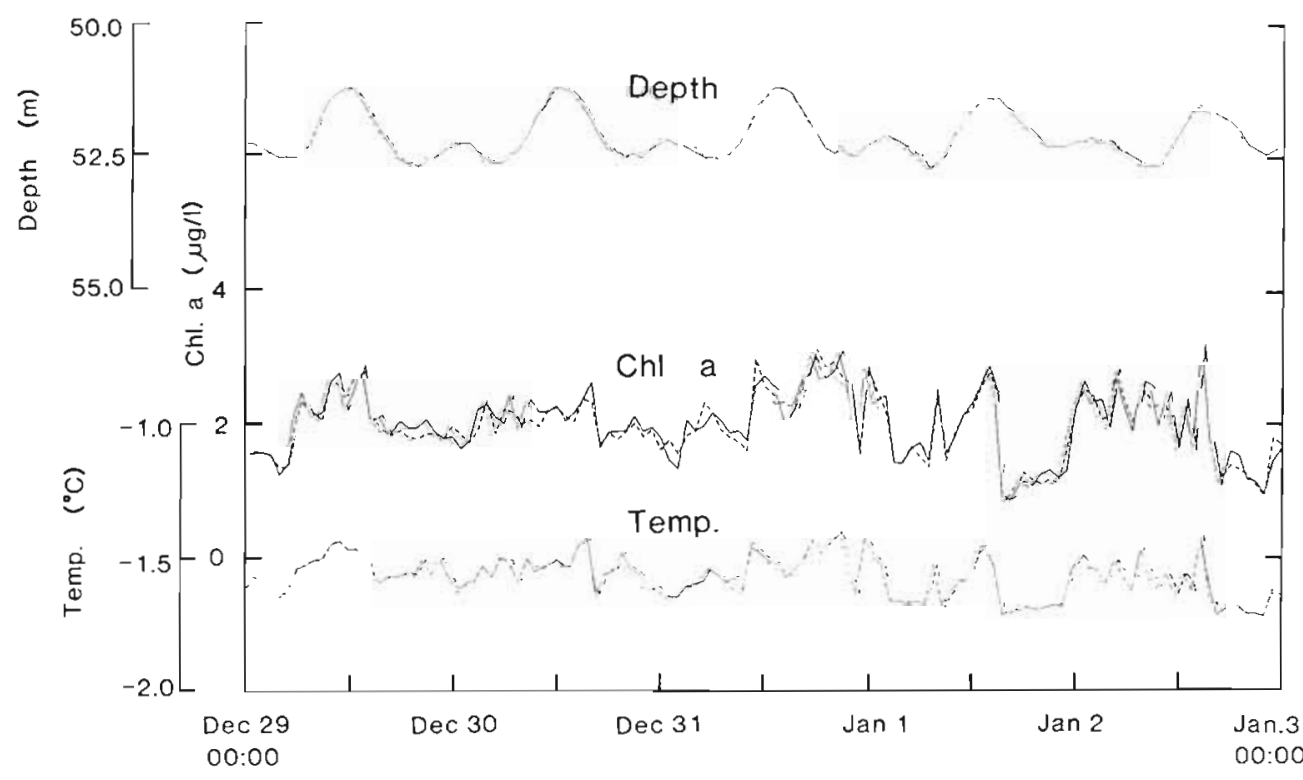




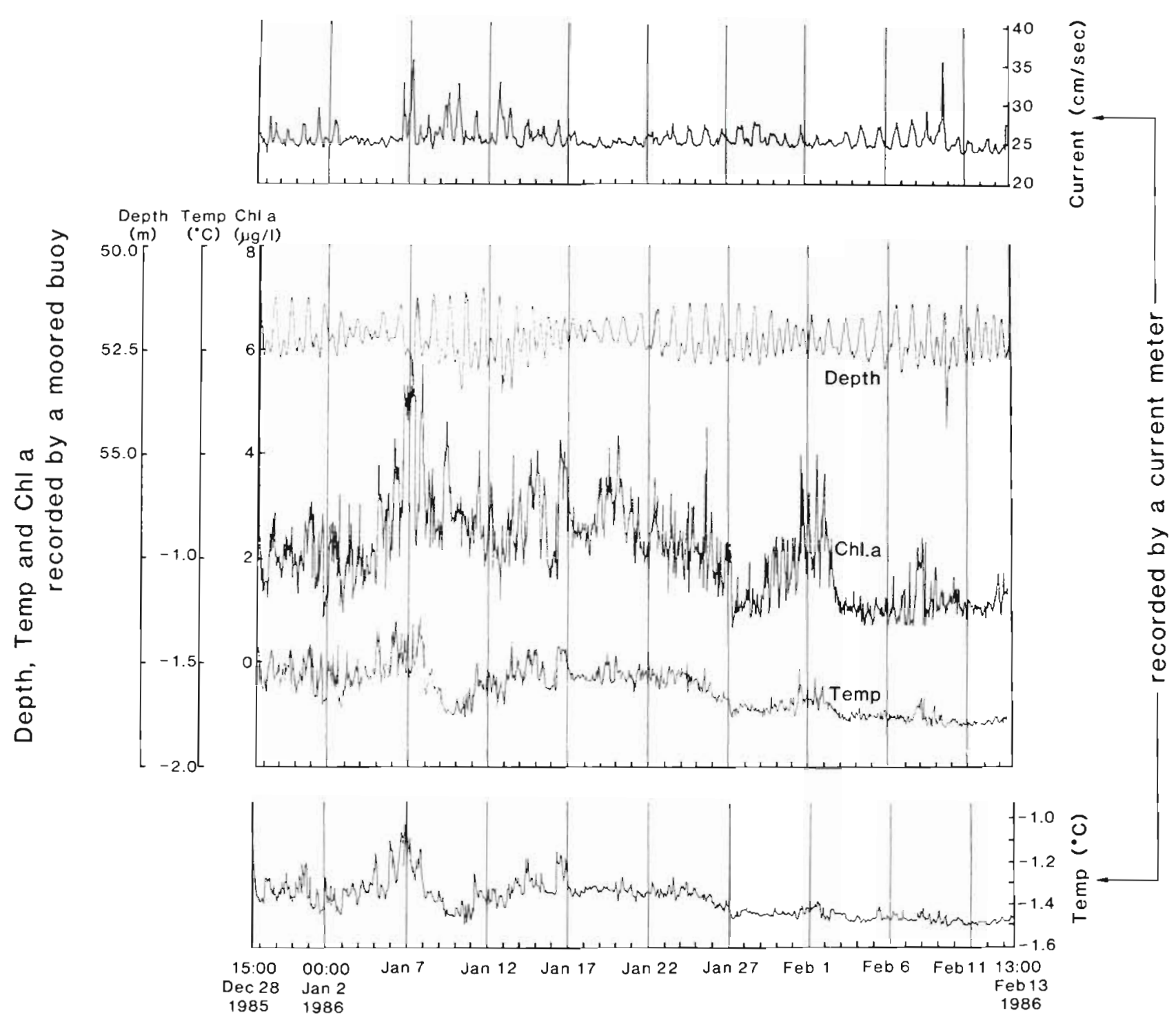

Fig. 7. Time series data over $47 \mathrm{~d}$ on depth, chlorophyll a and temperature measured by the buoy between 15:00 h LMT, 28 Dec 1985, and 13:00 h LMT, 13 Feb 1986, in Breid Bay, Antarctica. Data on current and temperature recorded by the current meter are also included

\section{DISCUSSION}

Whitledge \& Wirick (1983) first obtained time series chlorophyll data in marine waters. They used an in situ fluorometer with a telemetry system off Long Island, New York, USA. This system acquired data every $20 \mathrm{~min}$ for 10 and $11 \mathrm{~d}$ periods at depth $10.5 \mathrm{~m}$ in water depth $28 \mathrm{~m}$. Tin butoxide was used to minimize fouling of the fluorometer window. Later, Whitledge \& Wirick (1986) developed a moored fluorometer equipped with a mechanical window scrubber This system is capable of operating at depths up to $300 \mathrm{~m}$ for as long as 3 mo. However, they reported successful field tests for only 6 and $7 \mathrm{~d}$ periods. The system was deployed in relatively accessible areas (e.g. Long Island Sound and off Delaware Bay) in relatively shallow $(10$ and $60 \mathrm{~m})$ and relatively warm $\left(7\right.$ to $\left.9^{\circ} \mathrm{C}\right)$ waters.

The present chlorophyll-measuring buoy was moored in deeper water (286 $\mathrm{m}$ depth) and worked successfully for a period of $47 \mathrm{~d}$ at temperatures below $-1.2^{\circ} \mathrm{C}$. The present system thus appears to extend the operable range of moored fluorometers.

Because of irregularities in the bottom topography, our buoy was set below the subsurface chlorophyll maximum, which is the most representative of surface chlorophyll variation. However, the data show interesting time series information which is disussed later.

In Breid Bay, Antarctica, Steyaert (1973, 1974) 
Fig. 8. Scanning electron micrograph of sediment samples collected between 18:00 h LMT, 4 January and 06:00 h LMT, 8 January 1985 (Sample No. 3) showing dominancy of the centric diatom Thalassiosira antarctica. Bar = $50 \mu \mathrm{m}$

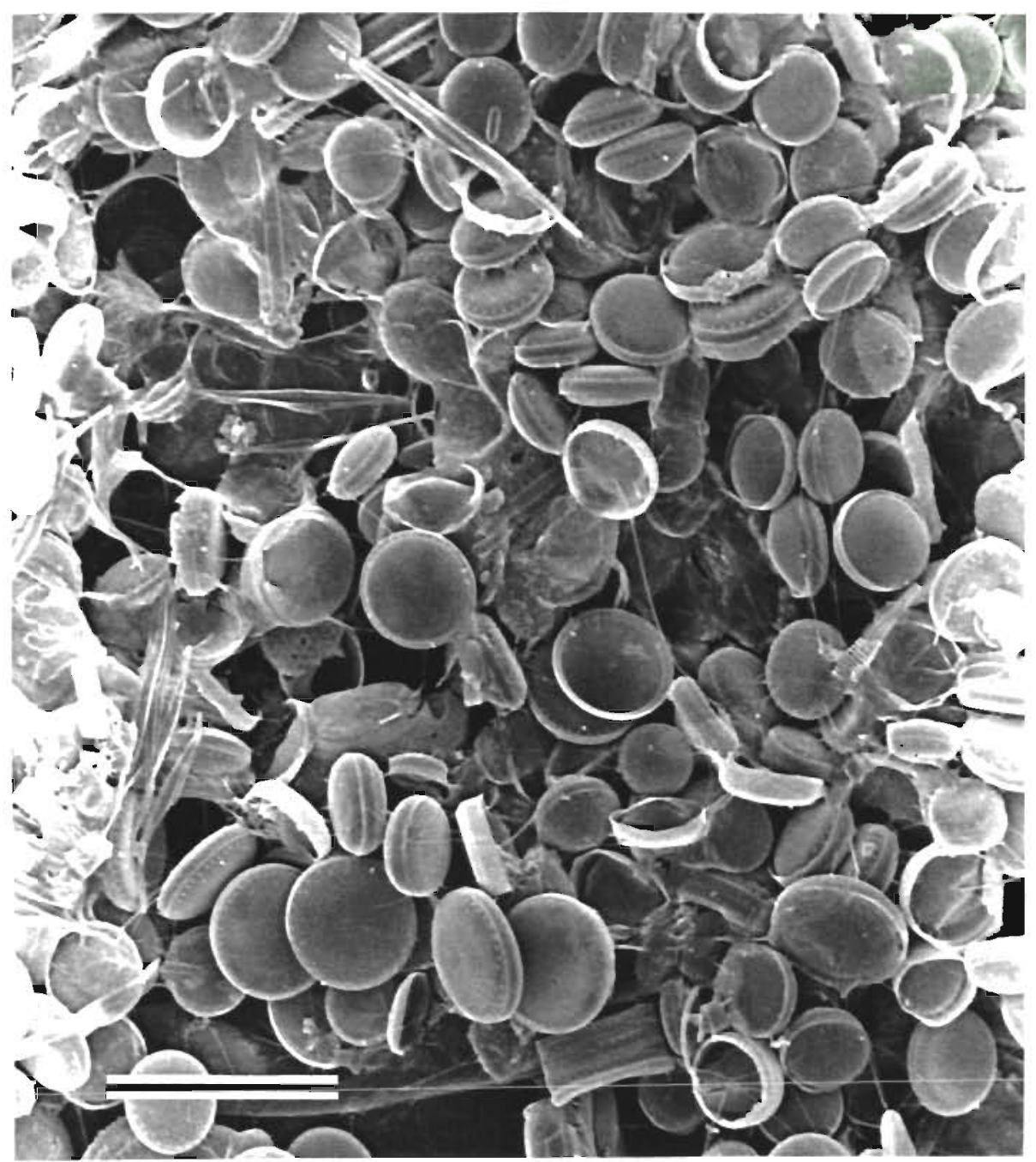

reported that distributions and abundances of diatoms in 2 summer periods (1964-65 and 1966-67) differed greatly from each other, primarily due to different hydrographic and sea ice conditions.

Other recent studies in Breid Bay (Fukuda et al. 1986, Taniguchi et al. 1986, Ohno et al 1987, Hattori \& Fukuchi unpubl.) found that the phytoplankton bloom differs greatly in time and magnitude from summer to summer. The approximate chlorophyll concentration $(5$ to $6 \mathrm{mg} \mathrm{m}^{-3}$ ) and standing stocks (300 to $400 \mathrm{mg} \mathrm{m}^{-2}$, 0 to $200 \mathrm{~m}$ ) were high. Chlorophyll abundance in the Bay is at least one order of magnitude higher than in antarctic open waters (El-Sayed \& Turner 1977, HolmHansen et al. 1977, Fukuchi 1981).

In the 1985-86 summer, the bloom had already started before the start of the mooring experiment in late December and had not yet terminated when the experiment ended in mid-February (Figs. 5 and 7). Therefore, the bloom in the coastal water continues for more than 2 to 3 mo when favorable conditions persist in summer.

Water temperature showed marked short-term (i.e. hourly or daily) fluctuations in the first half of the mooring period, but the fluctuations jecame smaller toward February. Long-term variation was also observed; temperature dropped steeply from 8 to 11 January, following a sudden temperature rise from 4 to 8 January. Short-term (hourly or daily) chlorophyll fluctuations were very evident throughout the observation period, while the fluctuation range became smaller toward February. Two marked peaks of chlorophyll a in early and late January coincided with those of high water temperatures.

According to the spectral analysis, the depth data showed 3 dominant periodicities which appear to be caused by tidal movements. No such periodicities were found in the chlorophyll a concentration and temperature data. 

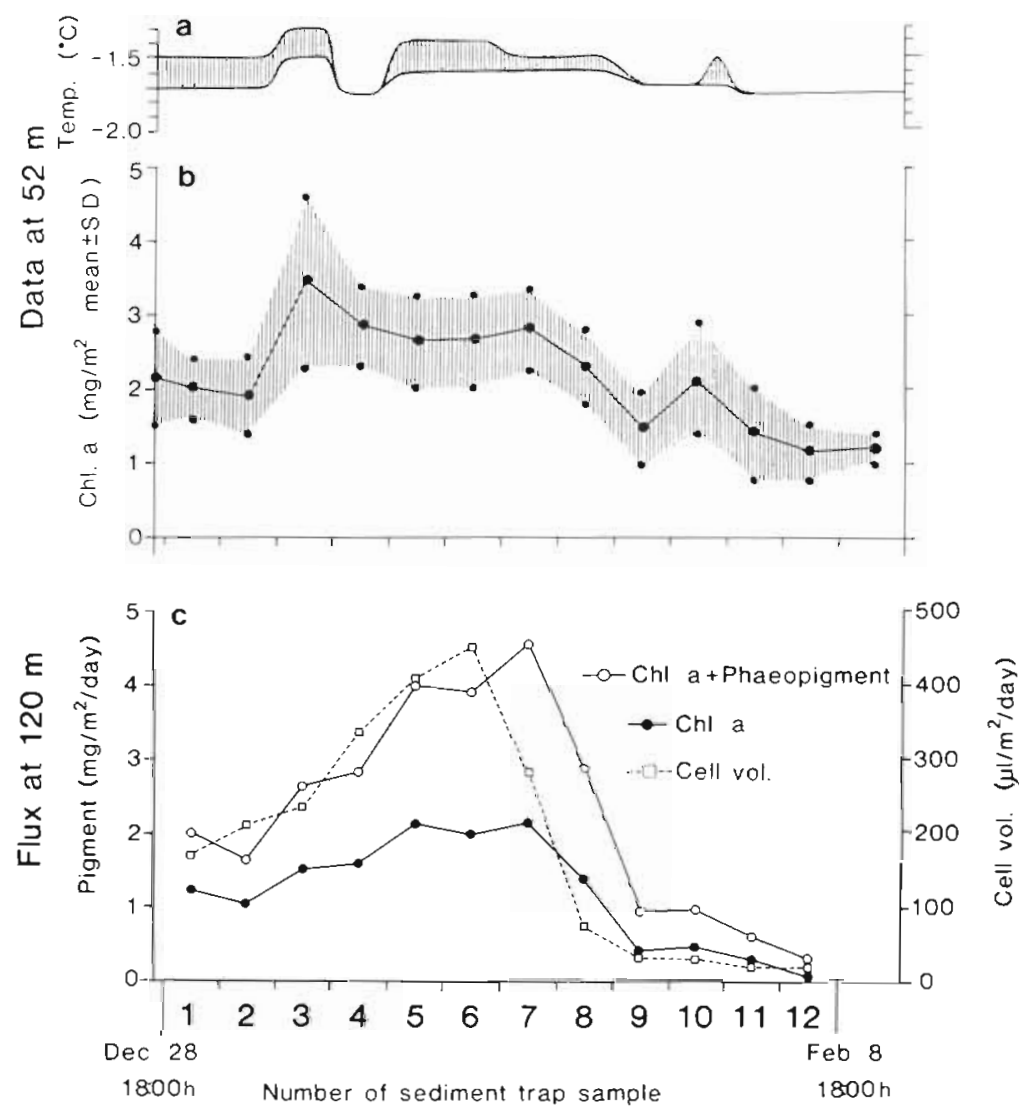

Fig. 9. Schematic representation of the bloom process, December 1985 to February 1986. Serial number of sediment trap sample (1 to 12) corresponds to $3.5 \mathrm{~d}$ intervals between $18: 00 \mathrm{~h}$ LMT, 28 Dec 1985 and 18:00 h LMT, 8 Feb 1986 (Table 2). (a) Temperature, and (b) chl a at $52 \mathrm{~m}$ depth; (c) pigment flux and cell volume at $120 \mathrm{~m}$

For each of 14 sampling periods (Table 2), no clear correlations were found between chlorophyll and depth or between depth and temperature. However, positive correlations were found between chlorophyll and temperature for all but one of these periods. One example of the correlation is shown for a $5 \mathrm{~d}$ period in Fig. 6.

A relatively constant current of $0.5 \mathrm{kn}$ (Fig. 7), possibly a tidal current, was observed throughout the period. Therefore, the short-term fluctuations in

Table 2. Regression coefficients and correlation coefficient between chlorophyll a and temperature calculated for each period corresponding to serial samplings of sediment trap. For relations between chlorophyll $a$ and depth, and between depth and temperature, only the correlation coefficient is calculated

\begin{tabular}{|c|c|c|c|c|c|c|c|}
\hline \multirow[t]{2}{*}{ Period } & \multirow{2}{*}{$\begin{array}{l}\text { (Sample no. } \\
\text { of sediment } \\
\text { trap) }\end{array}$} & \multirow{2}{*}{$\begin{array}{c}\text { Number } \\
\text { of } \\
\text { data }\end{array}$} & \multicolumn{2}{|c|}{ Chl $a=A$} & Temp. $+B$ & \multirow{2}{*}{$\begin{array}{c}\text { Chl a vs } \\
\text { Depth } \\
r\end{array}$} & \multirow{2}{*}{$\begin{array}{c}\text { Depth vs } \\
\text { Temp. } \\
r\end{array}$} \\
\hline & & & $A$ & $B$ & $r$ & & \\
\hline 28 Dec, $15: 00 \mathrm{~h}-28$ Dec, $17: 00 \mathrm{~h}$ & & 3 & 6.43 & 11.8 & 0.969 & -0.985 & -0.912 \\
\hline $28 \mathrm{Dec}, 18: 00 \mathrm{~h}-1 \mathrm{Jan}, 05: 00 \mathrm{~h}$ & (1) & 84 & 5.87 & 11.1 & 0.880 & -0.434 & -0.380 \\
\hline 1 Jan, 06:00 h- 4 Jan, 17:00 h & (2) & 84 & 6.64 & 12.4 & 0.866 & -0.118 & -0.174 \\
\hline 4. Jan, $18: 00 \mathrm{~h}-8 \mathrm{Jan}, 05: 00 \mathrm{~h}$ & (3) & 84 & 5.28 & 11.2 & 0.423 & 0.532 & -0.118 \\
\hline $8 \mathrm{Jan}, 06: 00 \mathrm{~h}-11 \mathrm{Jan}, 17: 00 \mathrm{~h}$ & (4) & 84 & -0.277 & 2.41 & -0.036 & -0.118 & -0.197 \\
\hline $11 \mathrm{Jan}, 18: 00 \mathrm{~h}-15 \mathrm{Jan}, 05: 00 \mathrm{~h}$ & (5) & 84 & 7.60 & 14.4 & 0.864 & -0.211 & -0.282 \\
\hline $15 \mathrm{Jan}, 06: 00 \mathrm{~h}-18 \mathrm{Jan}, 17: 00 \mathrm{~h}$ & (6) & 84 & 10.3 & 18.7 & 0.950 & 0.227 & 0.197 \\
\hline $18 \mathrm{Jan}, 18: 00 \mathrm{~h}-22 \mathrm{Jan}, 05: 00 \mathrm{~h}$ & (7) & 84 & 8.53 & 16.0 & 0.564 & -0.234 & -0.136 \\
\hline $22 \operatorname{Jan}, 06: 00 \mathrm{~h}-25 \mathrm{Jan}, 17: 00 \mathrm{~h}$ & $(8)$ & 84 & 8.22 & 15.2 & 0.561 & -0.252 & -0.208 \\
\hline 25 Jan, 18:00 h-29 Jan, 05:00 h & (9) & 84 & 11.3 & 20.6 & 0.866 & 0.141 & 0.122 \\
\hline 29 Jan, 06:00 h- 1 Feb, 17:00 h & $(10)$ & 84 & 13.3 & 24.5 & 0.862 & 0.168 & 0.028 \\
\hline 1 Feb, $18.00 \mathrm{~h}-5$ Feb, 05:00 h & (11) & 84 & 16.3 & 29.5 & 0.926 & -0.067 & -0.019 \\
\hline 5 Feb, 06.00 h- 8 Feb, $17: 00 \mathrm{~h}$ & $(1.2)$ & 84 & 12.2 & 22.4 & 0.793 & 0.209 & 0.258 \\
\hline 8 Feb, 18:00 h-13 Feb, 13:00 h & & 116 & 9.45 & 17.9 & 0.764 & 0.014 & -0.039 \\
\hline
\end{tabular}


chlorophyll suggest a patchy distribution of chlorophyll $a$ in the Bay.

Similar correlations between chlorophyll and temperature at $50 \mathrm{~m}$ depth were found at several stations around the mooring position in December and February. These observations also indicate a patchy distribution of phytoplankton and an advective water movement in the Bay. There are several peaks and plateaus of high chlorophyll which last for 3 to $5 \mathrm{~h}$ (Fig. 6). On the assumptions that the horizontal current speed was constant $(0.5 \mathrm{kn})$ and the phytoplankton was patchy, patch sizes were ca 1.5 to $2.5 \mathrm{n}$ miles. Whitledge \& Wirick (1986) also described the advective movement. of small phytoplankton patches as well as the diurnal variation and occurrence of a warm core ring. No diurnal variation was detected in the present study.

The reason for the lack of correlation between chlorophyll and temperature during Period 4 (Table 2) is not known, but it may be related in some way to an intrusion of cold water by a strong vertical mixing (Fig. 9a) that occurred during that period.

In the present study, a single diatom species, Thalassiosira antarctica, dominated the sediment samples in abundance. El-Sayed (1971) also observed large numbers of $T$. antarctica in patches in wide areas of the Weddell Sea. However, in other antarctic blooms, other species were found to be predominant. In Breid Bay, Steyaert (1973) found that Fragilariopsis curta, Nitzschia gr. Pseudonitzschia, Fragilariopsis (nana) and N. closterioides were predominant. Along the barrier edge of the Ross Ice Shelf, El-Sayed et al. (1983) reported an extensive bloom of the colonial flagellate Phaeocystis pouchetii.

The similarity in the pigment flux and volume flux curves (Fig. 9c) suggest that the pigment flux was largely due to the sinking of Thalassiosira antarctica. It is not known why the peaks in the pigment and volume fluxes differed by one sampling period.

If it is assumed that the gradual increase from sample No. 1 to sample No. 7 in pigment flux at $120 \mathrm{~m}$ (Fig. 9c) was due to the rapid increase in chlorophyll a from sample No. 2 to sample No. 3 at 52 m (Fig. 9b), then an estimate of the sinking rate of Thalassiosira antarctica can be made. The increase in pigment flux followed the increase in chlorophyll a by 3.5 to $10.5 \mathrm{~d}$. Thus,

$$
\text { sinking rate } \approx \frac{120-52 \mathrm{~m}}{3.5 \text { to } 10.5 \mathrm{~d}} \approx 6.5 \text { to } 19.4 \mathrm{~m} \mathrm{~d}^{-1} \text {. }
$$

These rates are higher than those of single phytoplankton cells (e.g. Smayda 1970). Probably, sinking cells of $T$. antarctica are chain-forming and the sinking rates become large.

Bodungen (1986) reported a pigment flux (sum of chlorophyll and phaeopigments) of $67.6 \mathrm{mg} \mathrm{m}^{-2}$ $(22.5 \mathrm{~d})^{-1}\left(=3 \mathrm{mg} \mathrm{m}^{-2} \mathrm{~d}^{-1}\right)$ between 27 November and
20 December 1983 from a sediment trap moored at $100 \mathrm{~m}$ depth in the Bransfield Strait, Antarctica. The present pigment flux of $95.2 \mathrm{mg} \mathrm{m}^{-2}(42 \mathrm{~d})^{-1}(=2.3 \mathrm{mg}$ $\left.\mathrm{m}^{-2} \mathrm{~d}^{-1}\right)$ is slightly lower than Bodungen's data. His sample was composed mainly of fecal pellets of krill Euphausia superba and zooplankton, but viable cells (mainly Thalassiosira antarctica) were less abundant. Bodungen (1986) reported that krill fecal pellets ranged in size from 300 to $1200 \mu \mathrm{m}$. The small number and small size $(<200 \mu \mathrm{m})$ of fecal pellets in our samples indicated that the krill were not an important predator of $T$. antarctica. Vertical pigment fluxes in the Antarctic Peninsula region in November-December 1980 were extraordinarily high ( 14 to $29 \mathrm{mg} \mathrm{chl} \mathrm{a} \mathrm{m}^{-2} \mathrm{~d}^{-1}$ ), and the main constituent of the trap sample was intact and apparently viable cells of $T$. antarctica (Bodungen et al. 1986). They suggested that $T$. antarctica sank to depths without heavy grazing pressure by zooplankton. We also found fewer fecal pellets in the trap samples, especially in the first half of the observation period. Based on our results and other results cited here, $T$. antarctica blooms may represent typical Antarctic blooms and this species may be a more important source of food for benthic than for planktonic animals.

Acknowledgements. We express our gratitude to Prof. Y. Yoshida, leader of the 27 th Japanese Antarctic Research Expedition, for his support of this research. We are also indebted to Captain A. Kurata of the icebreaker 'Shirase' and his officers and crew for their cooperation on board. Nichiyu Giken Kogyo Co. Ltd, Kawagoe, Japan, cooperated in designing and manufacturing the present mooring system. We thank Dr J. Raymond for critically reading the manuscript.

\section{LITERATURE CITED}

Bodungen, B. v. (1986). Phytoplankton growth and krill grazing during spring in the Bransfield Strait, Antarctica-Implications from sediment trap collections. Polar Biol. 6: 153-160

Bodungen, B. v., Smetacek, V., Tilzer, M. M., Zeitzschel, B. (1986). Primary production and sedimentation during spring in the Antarctic Peninsula region. Deep Sea Res. 33: $177-194$

El-Sayed, S. Z. (1971). Observations on phytoplankton bloom in the Weddell Sea. In: Llano, G. A., Wallen, I. E. (eds.) Antarct. Res. Ser. 17, Biology of the Antarctic Seas IV. Am. Geophysical Union, Washington, D. C., p. 301-312

El-Sayed, S. Z., Turner, J. T (1977). Productivity of the Antarctic and Tropical/Subtropical regions: a comparative study. In: Dunbar, M. J. (ed.) Polar oceans. Arctic Inst. North America, Calgary, Alberta, p. 463-503

El-Sayed, S. Z., Biggs, D. C., Holm-Hansen, O. (1983). Phytoplanktion standing crop, primary productivity, and nearsurface nitrogenous nutrient fields in the Ross Sea, Antarctica. Deep Sea Res. 30 (8A): 871-886

Fukuchi, M. (1981). Phytoplankton chlorophyll stocks in the Antarctic Ocean. J, oceanogr. Soc. Japan 36: 73-84

Fukuda, Y., Ohno, M., Fukuchi, M. (1986). Surface chlorophyll a distribution in marginal ice zone in Antarctica, 1984/85. Mem. Natl Inst. Polar Res. Spec. Issue 44: 24-33 
Herman, A. W., Mitchell, M. R. (1981). Counting and identifying copepod species with an in situ electronic zooplankton counter. Deep Sea Res. 28: 739-755

Holm-Hansen, O., El-Sayed, S. Z., Franceschini, G. A., Cuhel, R. L. (1977). Primary production and the factors controlling phytoplankton growth in the Southern Ocean. In: Llano G. A. (ed.) Adaptations within Antarctic ecosystem. Smithsonian Inst, Washington, D. C., p. 11-50

Jannasch, H. W., Zafiriou, O. C., Farrington, J. W. (1980). A sequencing sediment trap for time-series studies of fragile particles. Limnol. Oceanogr. 20:657-660

Longhurst, A. R., Williams, R. (1976). Improved filtration systems for multiple-serial plankton samplers and their deployment. Deep Sea Res. 23: 1067-1073

Nishio, F., Ishikawa, M., Ohnae, H., Takahashi, S., Katsushimna, T. (1984). A preliminary study of glacial geomorphology in area between Breid Bay and the Sor Rondane mountains in Queen Maud Land, East Antarctica. Antarct. Rec. 83: 11-28

Ohno, M., Fukuda, Y., Fukuchi, M. (1987). Vertical distribution and standing stocks of chlorophyll $a$ in the coastal water of the Antarctic Ocean. Antarct. Rec. 31: 93-108

Smayda, T.J. (1970). The suspension and sinking of phytoplankton in the sea. Oceanogr. mar. Biol. A. Rev. 8: 353-414
Steyaert, J. (1973). Difference in diatom abundance between the two summer periods of 1965 and 1967 in Antarctic inshore waters (Breid Bay). Investigación Pesq. 37 (3): $517-532$

Steyaert, J. (1974). Distribution of some selected diatom species during the Belgo-Dutch antarctic expedition of 1964-65 and 1966-67. Investigación Pesq. 38 (2): 259-287

Taniguchi, A., Hamada, E., Okazaki, M., Naito, Y (1986). Distribution of phytoplankton chlorophyll continuously recorded in the JARE-25 cruise to Syowa Station, Antarctica (SIBEX I). Mem. Natl Inst. Polar Res. Spec. Issue 44: $3-14$

UNESCO (1973). Monitoring life in the ocean. Tech. Pap. Mar Sci. 15: 71

Whitledge, I E., Wirick, C. D. (1983). Observations of chlorophyll concentrations off Long Island from a moored in situ fluorometer. Deep Sea Res. 30(3A): 297-309

Whitledge, T. E. Wirick, C. D. (1986). Development of a moored in situ fluorometer for phytoplankton studies. In: Bowman, T., Yentsch, M. Peterson, W. T (eds.) Lecture notes on coastal and estuarine studies, 17 . Tidal mixing and plankton dynamics. Springer-Verlag, Berlin, p. 449-462

Zeitzschel, B., Diekmann, P., Uhlmann, L. (1978). A new multisample sediment trap. Mar. Biol. 45: 285-288

This article was presented by Dr K. Sherman; it was accepted for printing on April 25, 1988 